\title{
JUURNAL.RU
}

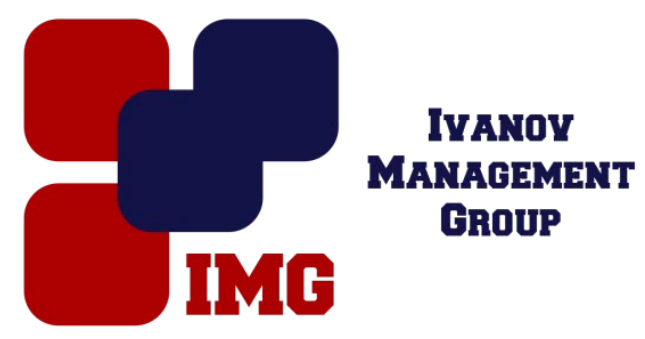

Дручек С.В., Мустафина А.А. Казанский Наииональный Исследовательский Технологический Университет Казань, Россия

doi: 10.18411/lj-30-11-2016-2-04

idsp 000001:lj-30-11-2016-2-04

\section{Исследование полимеров для технологии модифицированного сульфата кальция}

\begin{abstract}
Аннотация
Исследован способ модификации сульфата кальция с помощью различных видов полиакриламидов. Обнаружено, что в зависимости от вида полиакриламида, меняются свойства, такие как СНС, ДНС, растекаемость, время твердения, прочность. Анализ экспериментальных данных позволил установить, что лучшие характеристики имеют системы на основе полиакриламида FP-107.

Ключевые слова: сульфат кальция, полиакриламид.
\end{abstract}

\section{Введение}

Важность и изучение технологии модифицированного сульфата кальция связано с тем, что водные дисперсные системы сульфата кальция способны к твердению, и могут иметь широкое применение, в разных сферах промышленности. Поэтому исследование таких систем и их модификация представляет собой одну из актуальных задач.

Цель и задача работы заключались в подборе полимера, который будет сшиваться не более одного часа при различных температурах. В представленной работе приведены результаты экспериментальных исследований по модификации таких систем с помощью различных полимеров. В статье приведены экспериментальные данные по подбору оптимального полимера для использования в технологии модифицированного сульфата кальция.

\section{Экспериментальная часть}

В качестве химических реагентов использовались A-100HMW, A110HMW, A-130 LMW, A-150HMW, A-150LMW, A-190K, N-100, N-300, AN-132, FP-207, FP-107, A2051, А2951, вода, триацетат хрома p-p, гипс (Г-16).

Эксперимент проводился при помощи Вискозиметра OFITE 6скоростного, мешалки верхнеприводной, миксера высокоскоростного Hamilton. 
Замерили реологические параметры состава (пластическая вязкость, ДНС, CHC) при воздействии сдвиговых нагрузок на миксере Hamilton при 17000 об/мин. Сначала после окончания перемешивания на верхнеприводном перемешевателе (в течение 1 часа), затем после перемешивания 30 мин и 1 час на миксере Hamilton. Концентрации полимеров 12 кг/м3. Определили вмешиваемость гипса (Г-16) в полимерный раствор без создания высоких сдвиговых нагрузок. Время перемешивания и ввода 60 минут. При вводе гипса $(\Gamma-16)$ на широколопастном перемешивателе образование комков не наблюдалось. Гипс $(\Gamma-16)$ не осел в таком растворе. После перемешивания на высокоскоростной мешалке, стал вмешиваться лучше, но произошло оседание гипса (Г-16), и увеличилось время сшивания полимера.

Было использовано 28 рецептур. В таблице 1 представлены составы нескольких рецептур и их параметры.

Таблий 1.

\begin{tabular}{|c|c|c|c|}
\hline \multicolumn{4}{|c|}{ Составы рецептур } \\
\hline \multirow{2}{*}{ Рецептура } & \multicolumn{3}{|c|}{ Концентрация, кг/м ${ }^{3}$} \\
\hline & 1 & 2 & 3 \\
\hline FP-207 & 10 & - & - \\
\hline FP-107 & - & 10 & - \\
\hline AN-132 & - & - & 10 \\
\hline Вода & 630 & 630 & 630 \\
\hline Триацетат хрома (p-p) & 10 & 10 & 10 \\
\hline \multicolumn{4}{|c|}{ Параметры рецептур } \\
\hline Время гелирования при $50^{\circ} \mathrm{C}$, мин & 38 & 38 & 31 \\
\hline Начало твердения при $50^{\circ} \mathrm{C}$, мин & 180 & 250 & 250 \\
\hline онец твердения при $50^{\circ} \mathrm{C}$, мин & 190 & 260 & 260 \\
\hline Время гелирования при $20^{\circ} \mathrm{C}$, мин & 173 & 58 & 65 \\
\hline Начало твердения при $20^{\circ} \mathrm{C}$, мин & 200 & 260 & 260 \\
\hline Конец твердения при $20^{\circ} \mathrm{C}$, мин & 210 & 270 & 270 \\
\hline
\end{tabular}

В ходе эксперимента было принято решение дополнить методику. Взяли концентрацию полимера 10 кг/м3, растворяли на верхнеприводной мешалке в течение 1 часа. Замерили реологические параметры (ПВ, ДНС, СНС). Перемешивали 30 минут на миксере Hamiltonна первой скорости 11000 об/мин. Снова замерили реологические параметры (ПВ, ДНС, СНС). Если ДНС и СНС оказывались выше 35 фунт/100 фут2, вводились 5\%, 10\%, 15\% воды до достижения приемлемых показателей (25-35 фунт/100 фут2). Выбранная концентрация должна получиться в растворе затворения (к примеру, выбранная концентрация составила 10 кг/м3 в растворе полимера. В системе модифицированного сульфата кальция соответственно будет 6,3 кг/м3). Далее замеряли ПВ, ДНС, СНС и растекаемость при 20 0С. Если растекаемость была менее 200 мм, разбавляли следующим составом: вода 630 кг/м3, гипс (Г-16) 1000 кг/м3 до получения необходимой растекаемости 195-215мм (вводились дополнительно 5,10,15\%). Если растекаемость была менее 150 мм, то добавлялось 30\%. Замерили при комнатной температуре время гелирования, время твердения, прочность через сутки (в водной среде). На прочность 
ставилось по 2 кубика. Также оценили прочность геля в момент окончания гелирования (тест с трубкой). При слишком медленном гелировании состава, смотрели параметры твердения/гелирования/прочности при 50 0С.

Тест с трубкой представляет из себя тест на разрыв геля. В трубку длиной 300 мм и внутренним диаметром 24 мм заливался тестируемый состав. Трубку закрывалсь с обоих концов. При окончании гелирования образца свидетеля (по вискозиметру Брукфильда) извлекли состав из трубки и закрепили в лапках. Расстояние между лапками 200 мм, изначально гель был натянут так, чтобы прогиб был минимальным. Грузик подвешивался через специальный цилиндр длиной 50 мм для равномерного распределения нагрузки. Отслеживали при какой массе грузика начинал происходить разрыв геля. Замешивали на миксере Hamilton на скорости 11000 об/мин в течение 30 мин. После ввода в состав гипса (Г-16) и р-ра триацетата хрома сшивка и затвердевание состава в течение суток не наступили. Произошло выделение влаги.

На основании проведенного исследования из дальнейшего тестирования реагенты серии А и $\mathrm{N}$ были исключены. Они либо не образовывали геля при вводе гипса (Г-16), либо образовывали слабый гель перед затвердеванием. Далее работы были продолжены для уточнения граничных концентраций с реагентами FP-107, FP-207, AN-132. Определили диапазон концентрации полимеров, обеспечивающий хорошую вмешиваемость гипса $(\Gamma-16)$ при небольших скоростях сдвига, растекаемость 200-220 мм. Далее определили количество сшивателя, дающее наиболее прочную сшивку. Рецептура с AN-132 при вводе Гипса (Г-16)слишком сильно загущалась. AN-132 был исключен из дальнейшего тестирования. Рецептуры с реагентом FP-207 в сравнении с FP-107 давали меньшую прочность геля, сам раствор изначально несколько вязче (хуже растекаемость), время сшивки при низкой температуре больше. Дальнейшее тестирование проводилось для реагента FP-107, так как рецептура с содержанием 4 кг/м3 FP-107 показала удовлетворительную вязкость. На основании данных по рецептурам дальнейшие работы будем проводить с концентрацией сшивателя, превышающей концентрацию полимера на 30-40\%.

\section{Заключение}

Из целого спектра полимеров с различной молекулярной массой и зарядом был выбран реагент FP-107. Исследования показали, что именно этот полимер удовлетворяет требования ко времени гелирования, имеет лучшие по сравнению с другими пластические характеристики. В дальнейшем работы с FP-107 будут продолжены. 


\section{Литература}

1. М. Е. Позин, Р. Ю. Зинюк, Физико-химические основы неорганической технологии: Учеб. пособие для вузов. Химия, Ленинград, 1985, 384 с.

2. В. А. Киреев, Методы практических расчетов в термодинамике химических реакций. Химия, Москва, 1970, 520 с.

3. В. А. Хуснутдинов, Р. С. Сайфуллин, И. Г. Хабибуллин, Оборудование производств неорганических веществ: Учеб. пособие для вузов. Химия, Ленинград, 1987, 248 с. 